\title{
Permafrost distribution in the European Alps: calculation and evaluation of an index map and summary statistics
}

\author{
L. Boeckli ${ }^{1}$, A. Brenning ${ }^{2}$, S. Gruber ${ }^{1}$, and J. Noetzli ${ }^{1}$ \\ ${ }^{1}$ Department of Geography, University of Zurich, Switzerland \\ ${ }^{2}$ Department of Geography and Environmental Management, University of Waterloo, Ontario, Canada
}

Correspondence to: L. Boeckli (lorenz.boeckli@geo.uzh.ch)

Received: 7 February 2012 - Published in The Cryosphere Discuss.: 6 March 2012

Revised: 22 June 2012 - Accepted: 3 July 2012 - Published: 27 July 2012

\begin{abstract}
The objective of this study is the production of an Alpine Permafrost Index Map (APIM) covering the entire European Alps. A unified statistical model that is based on Alpine-wide permafrost observations is used for debris and bedrock surfaces across the entire Alps. The explanatory variables of the model are mean annual air temperatures, potential incoming solar radiation and precipitation. Offset terms were applied to make model predictions for topographic and geomorphic conditions that differ from the terrain features used for model fitting. These offsets are based on literature review and involve some degree of subjective choice during model building. The assessment of the APIM is challenging because limited independent test data are available for comparison and these observations represent point information in a spatially highly variable topography. The APIM provides an index that describes the spatial distribution of permafrost and comes together with an interpretation key that helps to assess map uncertainties and to relate map contents to their actual expression in the terrain. The map can be used as a first resource to estimate permafrost conditions at any given location in the European Alps in a variety of contexts such as research and spatial planning.

Results show that Switzerland likely is the country with the largest permafrost area in the Alps, followed by Italy, Austria, France and Germany. Slovenia and Liechtenstein may have marginal permafrost areas. In all countries the permafrost area is expected to be larger than the glacier-covered area.
\end{abstract}

\section{Introduction}

Permafrost in the European Alps is of practical and scientific interest, and the regional estimation of its distribution is described in numerous studies (e.g. Hoelzle, 1994; Imhof, 1996; Frauenfelder, 1998; Keller et al., 1998; Gruber and Hoelzle, 2001; Lambiel and Reynard, 2001; BAFU, 2005; Bodin, 2007; Ebohon and Schrott, 2008). Modelling strategies are not limited to the European Alps but have been developed for and applied to different mountain regions (e.g. Serrano et al., 2001; Tanarro et al., 2001; Janke, 2004; Lewkowicz and Ednie, 2004; Heggem et al., 2005; Etzelmüller et al., 2007; Lewkowicz and Bonnaventure, 2008; Li et al., 2009; Bonnaventure et al., 2012). Regional permafrost distribution models are typically based on empiricalstatistical relationships and give indications of permafrost distribution, with limited accuracy demands (Harris et al., 2009). PERMAKART (Keller, 1992) and PERMAMAP (Hoelzle, 1992; Hoelzle et al., 1993) were the first modelling approaches in the Alps that related topographic and climatic variables to the existence of permafrost and that provided map-based products to visualize permafrost distribution. Both models have been applied to various regions, and the basic relationships have been used/adapted for the development of further models (Imhof, 1996; BAFU, 2005; Ebohon and Schrott, 2008). As output, both models provide gridded data spatially predicting permafrost occurrence by using discrete classification schemes.

The existing work for the European Alps cannot easily be compiled into an Alpine-wide permafrost map, because the relevant studies (a) usually are regionally calibrated, (b) rely on differing methods, and (c) exclude large parts of the Alps. 
The present study is aimed to overcome these limitations and to provide one coherent Alpine Permafrost Index Map (APIM).

Based on a systematic collection of permafrost evidence (Cremonese et al., 2011), an Alpine-wide Permafrost MODel (APMOD) has been developed recently (Boeckli et al., 2012). Compared to previous studies, APMOD has a unique data basis that is distributed over the entire Alps. However, the difficult challenge that all permafrost distribution models have to deal with is that permafrost as a subsurface phenomenon cannot easily be detected at the terrain surface, and direct evidence for its presence or absence is generally rare. Therefore, model development is strongly limited by the type of calibration data available. As a consequence, the derivation of a map-based product from statistical models requires the inference of permafrost conditions in morphological settings other than those used for calibration. This task involves some degree of subjective choice during model application, which often is not declared or described in detail in previous work. This paper complements the study of Boeckli et al. (2012) by describing the required steps towards and the first results of an application of the APMOD.

Building upon the formulation of an Alpine-wide permafrost distribution model by Boeckli et al. (2012), the aims of this paper are

- to create a permafrost map (APIM) displaying index values based on model-derived probabilities of permafrost presence;

- to evaluate the APIM using independent data and discuss the general challenges inherent in this evaluation;

- to develop a legend and interpretation key that allow the efficient use of the APIM as well as the communication of its most important uncertainties; and

- to provide summary statistics regarding permafrost distribution in the Alps.

\section{A permafrost index based on a probability model}

The statistical model that is applied in this study, APMOD, is described in detail by Boeckli et al. (2012). APMOD is based on an Alpine-wide evidence collection (Cremonese et al., 2011) and uses mean annual air temperatures (MAAT), potential incoming solar radiation (PISR) and the mean annual sum of precipitation (PRECIP) as explanatory variables. APMOD involves two sub-models for two different land cover classes: The debris model has been calibrated using rock glacier inventories and predicts the probability of rock glaciers being intact as opposed to relict. The rock model is based on mean annual rock surface temperatures (MARST) and predicts the probability of finding MARST $\leq 0{ }^{\circ} \mathrm{C}$ in steep bedrock. Both models are combined based on fuzzy membership (linear function depending on slope angle,
Sect. 3.1) to the land cover types rock and debris, and allow the inclusion of temperature offset terms. These offset terms are required to generalize APMOD to other surface characteristics than those used for model calibration. When applied to digital elevation models (DEMs) of differing resolution, scaling functions improve the coherence and comparability of the results.

The probabilities of permafrost occurrence derived from APMOD are translated into permafrost index values, because the term "probability" is misleading and does not communicate the uncertainties and assumptions that are integrated in the final map-based product: The calibration of APMOD was not possible for many surface types, because permafrost observations are not available in sufficient quality and quantity. To derive a map-based product, we need to infer conditions where we have no data and the uncertainty of such predictions is difficult to assess. The term permafrost index thus avoids the notion of probability as we introduce some estimated additional factors (temperature offsets) and cannot evaluate true probability or extent. We suggest that the index represents an indicator of the probability for permafrost occurrence, the spatial percentage of permafrost per cell and/or the thickness of the permafrost body for current climatic conditions. The index can also be interpreted as a proxy of the mean annual ground temperature. However, permafrost extent, thickness or temperature cannot be allocated directly with the values of the index, because various local and regional processes are neglected or only approximated by the model.

\section{Data and methods}

The topographic and climatic variables that are required to apply APMOD are calculated according to Boeckli et al. (2012). In the following, data and methods are combined to derive an Alpine-wide surface cover that is considered in APIM (Sect. 3.1), and to prepare evaluation data for APIM (Sect. 3.2). Section 3.3 describes the method to derive Alpine-wide summary statistics.

The software R (version 2.14.1; R Development Core Team, 2010) was used for all statistical analyses. Terrain and geodata analyses were conducted with SAGA GIS (Olaya, 2004), "RSAGA" (Brenning, 2008) and "raster" (Hijmans and van Etten, 2012) packages for $\mathrm{R}$.

\subsection{Surface types}

A land cover map defining the two surface types (debris cover and steep bedrock) for the application of the two submodels is required for APMOD. A transition zone with varying degree of membership for the two surface types is used where APMOD is applied using a combination of the two sub-models (debris and rock model). In this paper, additional surface types are introduced as a spatial basis for addressing 
the offsets and assumptions described in Sect. 4. The following land surface types are differentiated and described below: debris cover, steep bedrock, vegetation and glacier coverage.

\subsubsection{Steep bedrock and debris cover}

The distinction between these two model domains is based on slope angle alone: We define an index $m_{r}$ by

$m_{r}^{\prime}=\frac{S-S_{\min }}{S_{\max }-S_{\min }}$

$m_{r}= \begin{cases}0 & \text { if } m_{r}^{\prime} \leq 0 \\ 1, & \text { if } m_{r}^{\prime} \geq 1 \\ m_{r}^{\prime} & \text { otherwise }\end{cases}$

which describes the degree of membership in the steep bedrock surface class, where $S$ is the slope angle of the grid cell, $S_{\min }$ is a fixed threshold angle up to which only debris cover occurs, and $S_{\max }$ is the assumed maximum slope angle up to which the surface may be debris-covered. To be consistent and applying the rock model to the same surface-cover domain as it was calibrated for, we use the same definition of steep bedrock as in Boeckli et al. (2012): "Steep bedrock" is defined as terrain that (a) is not or only marginally affected by a snow cover in wintertime, (b) does not contain large amounts of blocks and/or debris, and (c) is without vegetation coverage. Based on a literature review, Pogliotti (2010) summarizes that slope angles of $35-37^{\circ}$ represent the upper limit of usually well snow-covered areas $\left(S_{\min }\right)$ and slope angles of $55-60^{\circ}$ define the upper limit of snow accumulation $\left(S_{\max }\right)$. Analysing the distribution of slope angle values within training areas representing debris respectively, bedrock cover (Fig. 1) indicates similar values for the two thresholds based on the data used here. The training areas were derived from the land cover map of Switzerland (Vector25, swisstopo, 2007) using randomly distributed points $(N=4029$ for rock and $N=4381$ for debris cover). Here, the distribution of slope angle values is biased because bedrock is also possible in flat terrain (e.g. glacier forefields), and the points that are used for this analysis are sparse for very steep slopes.

Finally, $S_{\min }$ was set to $35^{\circ}$, which coincides with the start of a strong increase in the presence of exposed bedrock (Fig. 1) and $S_{\max }$ was set to $55^{\circ}$. Slopes with greater slope angles in the DEM rarely present debris surfaces (Fig. 1), and these can likely be attributed to errors in the DEM. To address point (c) above, we assume a debris cover $\left(m_{r}=0\right)$ if the surface is covered by vegetation (see below).

\subsubsection{Vegetation}

The discrimination of vegetation from vegetation-free surfaced areas is based on the soil-adjusted vegetation index (SAVI; Huete, 1988) and is derived from Landsat Thematic

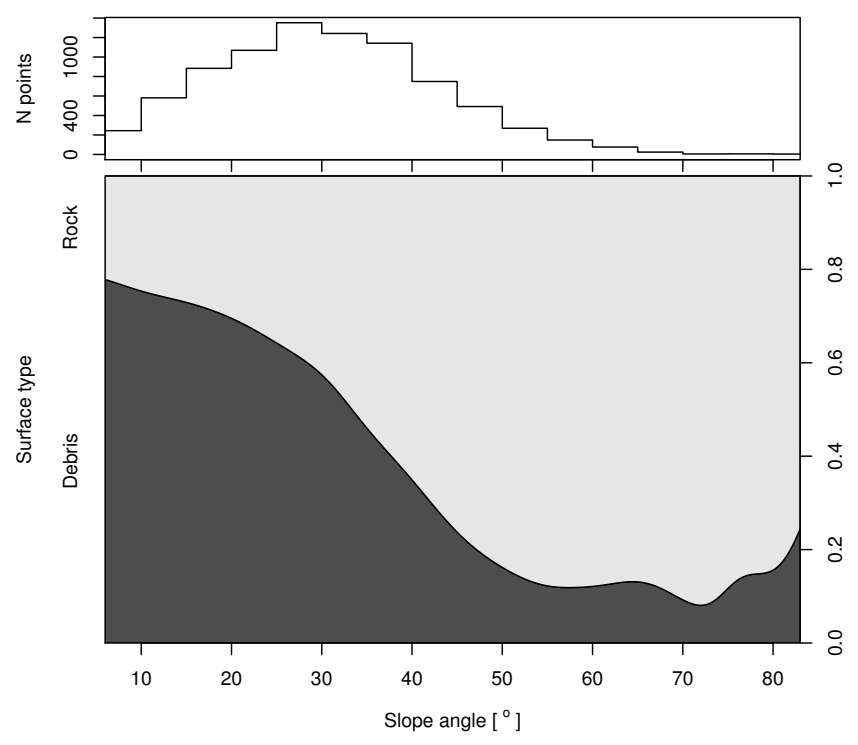

Fig. 1. Conditional density plot for the two surface classes debris and rock (derived from Vector25) in relation to slope angle. Above, the number of points that are used for this analysis are shown in relation to slope angle.

Mapper (Landsat 5) and Landsat Enhanced Thematic Mapper (Landsat 7) images using red and near-infrared (NIR) wavelengths. SAVI accounts for the soil-induced influences on vegetation index values and involves an additional constant $L$ to the formula of the normalized difference vegetation index (NDVI):

$\mathrm{SAVI}=\frac{\mathrm{NIR}-\mathrm{red}}{\mathrm{NIR}+\operatorname{red}+L}(1+L)$.

$L$ was set to 1 , since this value is suitable for characterizing low vegetation densities (Huete, 1988) present in mountainous vegetation. Thirteen scenes cover the entire Alpine region. Only images taken in August/September/October were used, since vegetation is still well-developed as evidenced by remotely sensed phenology (cf. Fontana et al., 2008) and snow cover is likely near its annual minimum. For each of the 13 scene locations, the scene with lowest cloud cover was chosen (Table 1). After calculating the SAVI values, all 13 grids were merged (by using the maximum SAVI value in areas of overlap) and resampled with bilinear interpolation to the resolution of ASTER GDEM.

A threshold for discriminating vegetation from vegetationfree surfaced areas was chosen by analysing SAVI values in training areas derived from Vector25. The training data consist of randomly distributed points: 42797 for vegetation and 8419 for vegetation-free areas. The Vector 25 land cover classes rock and debris were treated as vegetation-free areas, while forest, open forest, bush land and remaining areas were classified as vegetation. Finally, optimizing the $\kappa$ coefficient (Cohen, 1960) as a function of the SAVI threshold, pixels with SAVI $<0.335$ are considered free of vegetation, 
Table 1. Landsat scenes used to calculate the SAVI.

\begin{tabular}{llll}
\hline Path & Row & Date $(\mathrm{d} / \mathrm{m} / \mathrm{y})$ & Sensor \\
\hline 191 & 27 & $14 / 10 / 2006$ & Landsat 5 \\
191 & 28 & $14 / 10 / 2006$ & Landsat 5 \\
192 & 27 & $05 / 10 / 2006$ & Landsat 5 \\
192 & 28 & $22 / 08 / 2007$ & Landsat 5 \\
193 & 27 & $20 / 10 / 2003$ & Landsat 5 \\
193 & 28 & $34 / 08 / 2003$ & Landsat 5 \\
194 & 27 & $21 / 08 / 2000$ & Landsat 7 \\
194 & 28 & $32 / 10 / 2002$ & Landsat 7 \\
195 & 27 & $24 / 08 / 2006$ & Landsat 5 \\
195 & 28 & $18 / 10 / 2003$ & Landsat 5 \\
195 & 29 & $06 / 09 / 2002$ & Landsat 7 \\
196 & 28 & $23 / 08 / 2003$ & Landsat 5 \\
196 & 29 & $23 / 08 / 2003$ & Landsat 5 \\
\hline
\end{tabular}

and pixels with $\mathrm{SAVI} \geq 0.335$ are classified as vegetation. Further, a median filter $(3 \times 3$ cells $)$ was applied to remove artifacts, and all pixels where $m_{r}=1$ (steep bedrock) were considered free of vegetation.

\subsubsection{Glaciers}

Glacier outlines derived from Landsat images were provided by Paul et al. (2011). The outlines represent glacier extent in the year 2003, manually corrected for debris-covered glacier parts.

\subsection{Evaluation of a permafrost index map}

The evaluation data are based on rock glaciers and point observations of permafrost presence and absence. Status information (intact vs. relict) of rock glaciers can be used to evaluate the output of APMOD in areas covered by rock glaciers. As a result of matched sampling, Boeckli et al. (2012) excluded 394 intact and 2403 relict rock glaciers from model fitting. They are available for model evaluation in the debris cover domain (Fig. 2). Further 352 observation points are available within the permafrost evidence collection (Fig. 2; Cremonese et al., 2011) that were not used for model calibration. These observations are based on different methods and were classified as permafrost presence or absence by each individual data contributor. This classification was also rated by the data contributor with an index that describes the certainty of this classification $\left(\mathrm{PF}_{\text {cert }}\right)$. The point observations allow to evaluate the map for other types of surfaces.

An additional measure describing the agreement of the terrain attributes $\left(\mathrm{PF}_{\text {loc }}\right)$ was calculated for each observation point. This is necessary because some observation points are not suitable for model evaluation and needed to be excluded beforehand, which will be discussed in Sect. 6.2. However, the weighting scheme applied to derive $\mathrm{PF}_{\text {loc }}$ is based on subjective thresholds.

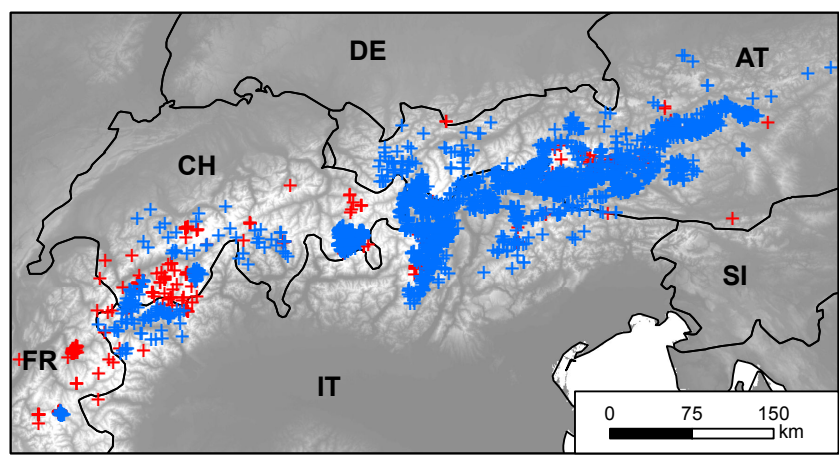

Fig. 2. Spatial distribution of permafrost evidence data (Cremonese et al., 2011), which were not used for model calibration in Boeckli et al. (2012) and are thus available for evaluation. Blue dots represent rock glaciers, and red crosses represent evidence points (summarized in Table 3).

Table 2. Thresholds and corresponding weights per variable that were used to characterize the agreement of the terrain attributes $\left(\mathrm{PF}_{\text {loc }}\right)$ for the evaluation data. The weight for the variable aspect for slope angles $\leq 15^{\circ}$ (derived from ASTER GDEM) was fixed to 2 , because uncertainties in this variable are large for flat terrain.

\begin{tabular}{lrrr}
\hline Weights & $\begin{array}{r}\text { Elevation } \\
(\mathrm{m})\end{array}$ & $\begin{array}{r}\text { Slope angle } \\
\left({ }^{\circ}\right)\end{array}$ & $\begin{array}{r}\text { Aspect } \\
\left({ }^{\circ}\right)^{*}\end{array}$ \\
\hline 2 & $<100$ & $<10$ & $<25$ \\
1 & $100-250$ & $10-25$ & $25-50$ \\
0 & $>250$ & $>25$ & $>50$ \\
\hline
\end{tabular}

* Only applied to observations with a slope angle $>15^{\circ}$.

The terrain variable elevation, slope angle and aspect were derived from the digital elevation model ASTER GDEM (Hayakawa et al., 2008) for all 352 observation points and then compared to the values that were manually entered by the data provider into the permafrost evidence database. It is not possible to automatically differentiate errors in the evidence metadata from the effects of sub-grid variability with this method. It is, however, useful to have this index of topographical agreement for the interpretations of differences in the comparison and for further investigating possible errors in the evidence data. Differences in aspect values $\left(\Delta_{\mathrm{A}}\right)$ were calculated using the absolute difference between aspect angles modulo $360^{\circ}$ in the interval $\left(-180^{\circ}, 180^{\circ}\right)$. Absolute differences in elevation, slope and aspect angle (Fig. 3) were used to manually define thresholds and to weight these differences (Table 2). The weight of the variable aspect was disregarded for slope angles $\leq 15^{\circ}$, because uncertainties in this variable are large for flat terrain. Multiplying the assigned weights for the three measures elevation, slope angle and aspect for each observation results in values ranging from 0 to 8 , where a value $\geq 4$ is classified as "agree", a value of 1-2 "disagree" and a value of 0 "strongly disagree" (Table 3 ). The multiplication of the three weights implies that an 

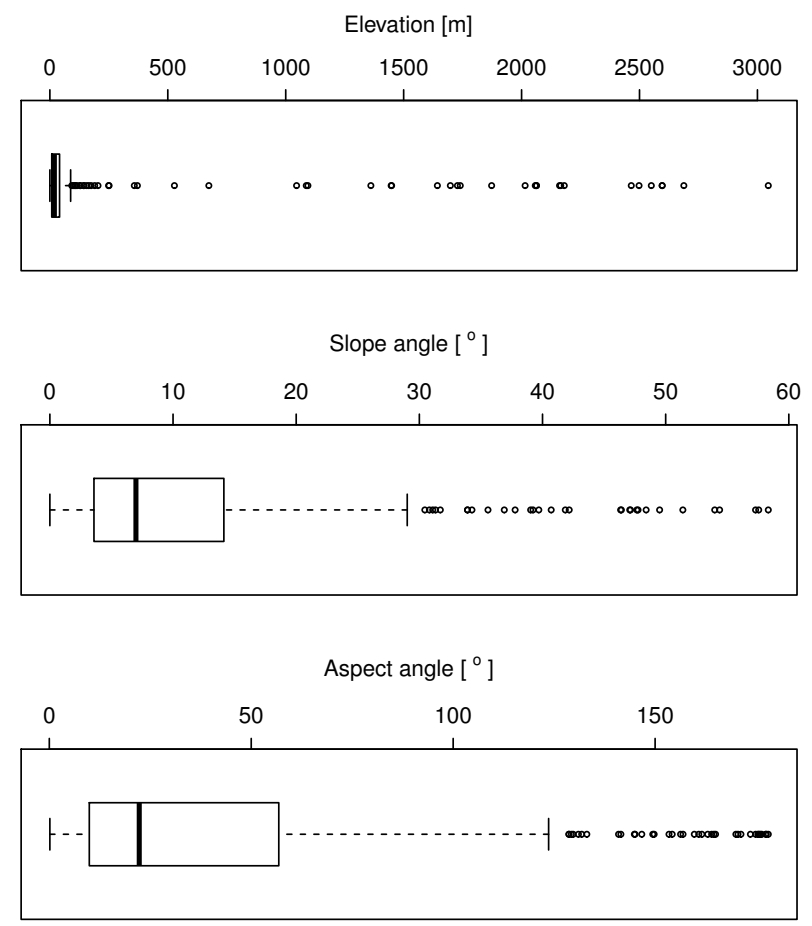

Fig. 3. Absolute difference between terrain variables calculated based on ASTER GDEM and the ones provided by the data contributor into the permafrost evidence collection (Cremonese et al., 2011).

observation with one of the three measures $=0$ is classified as "strongly disagree", whatever the other two measures are.

Permafrost point-observations with $\mathrm{PF}_{\text {cert }}$ equals "quite likely" and $\mathrm{PF}_{\text {loc }}$ equals "strongly disagree" are not considered for model evaluation, and the following evidence types from Table 3 were also excluded from evaluation: (a) ground surface temperatures were not considered because of the large inter-annual variability caused by the influence of the snow cover (Hoelzle et al., 2003; Brenning et al., 2005); (b) rock fall scars were excluded because only 4 observations remained after removing observations with $\mathrm{PF}_{\text {loc }}$ equals "strongly disagree"; (c) surface movements were not considered because only four observations are available; and (d) other indirect evidence was excluded because no additional information regarding measurement or observation type is available.

To assess the discrimination of the permafrost index, the area under the receiver-operating characteristics curve (AUROC, Mason and Graham, 2002) was measured. This measure ranges from 0.5 (random discrimination) and 1 (perfect discrimination).

\subsection{Calculation of summary statistics}

The term "permafrost index area" will be used to present the result and refers to the area having an index equal to or higher than a specified threshold. Glaciers are excluded from the permafrost index areas. It is important to note the difference to permafrost area that would be defined as the surface actually underlain by permafrost (cf. Zhang et al., 2000; Gruber, 2012). The index area is the unit of interest for decisionmaking ("Where do I need to consider permafrost?") and the actual result of the model presented. Permafrost area may be important, e.g. for estimating water storage in subsurface ice, but is more difficult to support by reliable data.

Pixel area of the unprojected ASTER GDEM grid depends on latitude $(\phi)$ and the mean radius of the Earth $(R=$ $6371 \mathrm{~km})$. North-south $(\Delta y)$ and west-east $(\Delta x)$ for the $1^{\prime \prime}$ spherical grid were used to calculate the area:

$\Delta y=\frac{\pi R}{648000}$ and $\Delta x=\cos (\phi) \Delta y$

\section{Estimation of offset terms}

The MARST used for model calibration were measured in homogenous rock following the procedure outlined in Gruber et al. (2003). This provides a quantification of the influence of topography on rock temperatures, but likely temperatures at greater depth in most rock faces are lower due to effects of snow, debris and fracturing (Gruber and Haeberli, 2007). To address this, a temperature-offset term is included in the rock model that is based on literature: Measurements in the Swiss Alps showed that the spatial variation of temperature offset in rock faces is large and mainly depends on (a) radiation exposure (Hasler et al., 2011), (b) snow depth and its timing (cf. Pogliotti, 2010) and (c) the amount and characteristics of cleft systems at the rock surface (Hasler et al., 2011). Summarizing these three factors, Hasler et al. (2011) postulate that radiation-exposed steep rock faces with interspersed snow patches and/or large fractures are up to $3{ }^{\circ} \mathrm{C}$ colder at depth (i.e. in the order of a few meters) compared to MARST in snow-free and compact rock. In north-exposed situations, the effect of snow and/or fractures is less important, because short-wave radiation is less dominant. Based on these findings, the offset term $\Delta_{R}$ was implemented as a linear function of PISR and applied to the rock model:

$\Delta_{\mathrm{R}}=O_{\min }+\operatorname{PISR} \frac{O_{\max }-O_{\min }}{350 \mathrm{~W} \mathrm{~m} \mathrm{~m}^{-2}}$,

where $O_{\min }$ is the minimal and $O_{\max }$ is the maximal offset for pixels where PISR $=350 \mathrm{~W} \mathrm{~m}^{-2}$. The percentile of $350 \mathrm{~W} \mathrm{~m}^{-2}$ is 0.88 in the cumulative distribution function of PISR values. $O_{\min }$ was set to -0.5 and $O_{\max }=-2.5$. Spatial variation of $\Delta_{R}$ is not considered.

The debris model provides an optimistic estimate (biased towards an overestimation) of permafrost occurrence in debris surfaces because of three main rock glacier characteristics: (a) cooling effect of coarse block surface (e.g. Haeberli et al., 2006), (b) rock glacier movement towards lower elevations (e.g. Barsch, 1978), and (c) delayed response of ice-rich 
Table 3. Overview of the different observation types (BH: borehole, GST: ground surface temperature, SC: rock fall scar, TR: trench and construction site, SM: surface movement, GP: geophysical investigation, OIE: other indirect evidence) that remain for evaluation. For each type, the number of permafrost-existence $\left(\mathrm{PF}_{\text {yes }}\right)$ and permafrost-absence $\left(\mathrm{PF}_{\mathrm{no}}\right)$ observations is given $($ Certainty levels $\mathrm{PF}$ cert: 1 definite proof, 2 quite certain, 3 quite likely; Agreement levels $\mathrm{PF}_{\text {loc }}$ : a agree, d disagree, s strongly disagree).

\begin{tabular}{rrrr|rrr}
\hline Type & $\mathrm{PF}_{\text {yes }}$ & $\mathrm{PF}_{\text {cert }}(1 / 2 / 3)$ & $\mathrm{PF}_{\mathrm{loc}}(\mathrm{a} / \mathrm{d} / \mathrm{s})$ & $\mathrm{PF}_{\text {no }}$ & $\mathrm{PF}_{\text {cert }}(1 / 2 / 3)$ & $\mathrm{PF}_{\text {loc }}(\mathrm{a} / \mathrm{d} / \mathrm{s})$ \\
\hline $\mathrm{BH}$ & 45 & $36 / 6 / 3$ & $22 / 3 / 20$ & 16 & $11 / 5 / 0$ & $11 / 1 / 4$ \\
$\mathrm{GST}$ & 49 & $18 / 25 / 6$ & $37 / 3 / 9$ & 41 & $3 / 16 / 22$ & $34 / 1 / 6$ \\
$\mathrm{SC}$ & 36 & $6 / 30 / 0$ & $3 / 1 / 32$ & - & - & - \\
$\mathrm{TR}$ & 38 & $25 / 12 / 1$ & $22 / 0 / 16$ & 9 & $3 / 6 / 0$ & $6 / 2 / 1$ \\
$\mathrm{SM}$ & 4 & $2 / 2 / 0$ & $3 / 0 / 1$ & - & - & - \\
$\mathrm{GP}$ & 70 & $29 / 35 / 6$ & $61 / 4 / 5$ & 11 & $3 / 8 / 0$ & $11 / 0 / 0$ \\
$\mathrm{OIE}$ & 33 & $7 / 19 / 7$ & $23 / 4 / 6$ & - & - & - \\
\hline
\end{tabular}

Table 4. Temperature offsets $\left({ }^{\circ} \mathrm{C}\right)$ that were applied to the different surface types. A positive sign means a positive temperature offset is applied, which results in a more pessimistic permafrost estimate. A negative sign means a more optimistic permafrost estimate.

\begin{tabular}{lllll}
\hline Surface cover & $\Delta_{\mathrm{R}}$ & $\Delta_{\mathrm{Da}}$ & $\Delta_{\mathrm{Db}}$ & total offset \\
\hline Steep bedrock & {$[-0.5,-2.5]$} & - & - & {$[-0.5,-2.5]$} \\
Debris cover & - & 0.5 & - & 0.5 \\
Vegetation & - & 0.5 & 2 & 2.5 \\
\hline
\end{tabular}

permafrost to climatic forcing (e.g. Frauenfelder et al., 2008). Consequently, it is desirable to find relationships to infer conditions below surfaces other than rock glaciers. The first two sources of bias are considered in this study, while the third remains unaccounted for due to a lack of information that would allow its estimation.

By moving down-slope, a rock glacier transports a cold and ice-rich mass from its rooting zone to conditions that may be less favourable for the formation of permafrost. The melting of ice as a result of an increase in active layer thickness can thus exert a cooling influence at depth and preserve permafrost where it would not form without the advection of ice-rich material. We approximate the magnitude of this effect by the altitudinal extent of rock glaciers, i.e. the difference in elevation between the lowest and highest point of each rock glacier, assuming that in the Alps only the rooting zone of a rock glacier shows conditions for the development of ice-rich permafrost. For the 5541 rock glaciers in the inventory of Cremonese et al. (2011), the mean altitudinal extent is $139 \mathrm{~m}$. In APMOD, a random point within each rock glacier is taken for model calibration (Boeckli et al., 2012), which, on average, corresponds to the centroid of the rock glacier. Accordingly, the altitudinal extent is divided by two resulting in a bias correction of $70 \mathrm{~m}$, which corresponds to an approximate difference in MAAT of $0.5^{\circ} \mathrm{C}$ (assumed surface temperature lapse rate $0.0065^{\circ} \mathrm{C} \mathrm{m}^{-1}$, cf. International Organization for Standardization, 1975). This value is chosen for the movement-related offset $\left(\Delta_{\mathrm{Da}}\right)$ and applied to the debris model.

A surface cover of coarse blocks with no or little infill by fine material usually results in markedly colder MAGT than, for example, fine moraine-derived soil or solid bedrock. This effect has been measured and discussed by several researchers (e.g. Humlum, 1997; Harris and Pedersen, 1998; Gorbunov et al., 2004; Hanson and Hoelzle, 2005; Gruber and Hoelzle, 2008; Gubler et al., 2011). Ground temperatures of coarse blocks in comparison to finer grained material may be $1.3-2{ }^{\circ} \mathrm{C}$ (Juliussen and Humlum, 2008) to $4-7^{\circ} \mathrm{C}$ (Harris and Pedersen, 1998) colder. $1.6^{\circ} \mathrm{C}$ to $2.2^{\circ} \mathrm{C}$ reduction of MAGT with respect to finer grained material was observed during one year at Corvatsch (Switzerland) for a large data set containing 390 temperature sensors distributed in 39 footprints (Gubler et al., 2011). Accordingly, an offset of $2{ }^{\circ} \mathrm{C}$ $\left(\Delta_{\mathrm{Db}}\right)$ is implemented in the debris model to address the effect of coarse blocks.

While $\Delta_{\mathrm{Da}}$ is applied to the whole domain of the debris model, $\Delta_{\mathrm{Db}}$ is applied to vegetated areas only, because these areas are normally characterized by fine-grained debris and can be detected by remote sensing for the entire Alps. Several studies indicate that, in the European Alps, a closed vegetation cover usually indicates the absence of permafrost (Haeberli, 1975; Hoelzle et al., 1993). This relationship is not necessarily true in all situations (e.g. Delaloye et al., 2003), but provides a valuable indication. In the context of APIM, we regard a closed vegetation cover to be indicative of fine material and thus the absence of open-work block cover. Therefore, the above-mentioned offset $\left(\Delta_{\mathrm{Db}}\right)$ addressing coarse blocks is applied to account for thermal differences between non-vegetated and vegetated areas.

\section{Results}

\subsection{Interpretation key for the permafrost index}

A sample map of APIM is shown for the entire Alps (Fig. 4) and the Rimpfischhorn in Switzerland (Fig. 5). The map 


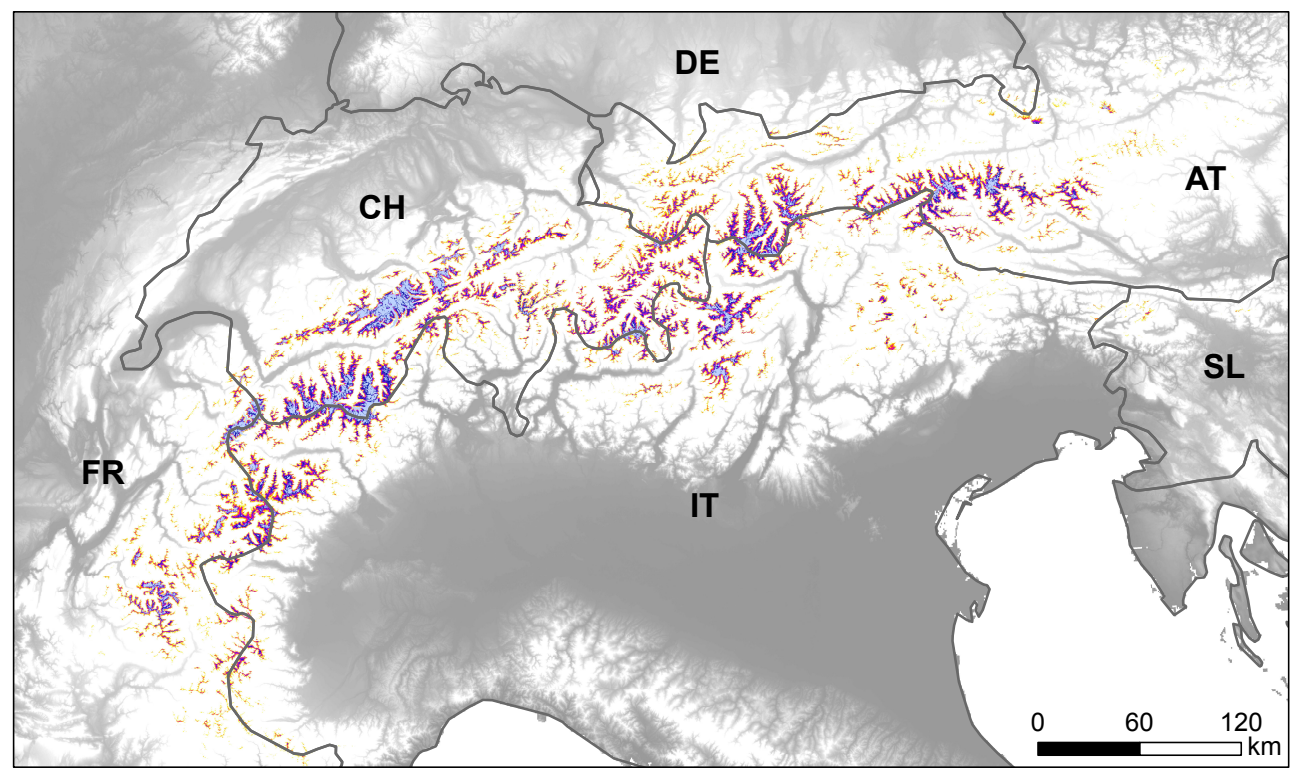

Fig. 4. Alpine Permafrost Index Map (APIM) shown for the European Alps (AT: Austria, CH: Switzerland, DE: Germany, FR: France, IT: Italy, SL: Slovenia). The map should be interpreted together with the legend and interpretation key (Fig. 10).

should be used with the provided legend and interpretation key (Fig. 10). An additional map showing the surface types (Fig. 6) is necessary in order to understand the statistical model parameters and to interpret the shown index value more accurately.

The aim of the interpretation key provided with the permafrost index map is to allow efficient use and understanding of the map and to communicate the most important uncertainties for practical use, e.g. by public authorities or for infrastructure planning and maintenance. It consists of three parts: (a) the legend itself and an accompanying text, (b) an interpretation key that allows to refine the estimate shown in the map based on additional surface cover observations (e.g. based on air photo interpretation), and (c) a description and a legend explaining the auxiliary surface-cover map provided (Fig. 10). The index varies from "permafrost in nearly all conditions" to "permafrost only in very favourable conditions" and describes semi-quantitatively the occurrence of permafrost. The term "very favourable conditions" refers to a situation (topography and ground characteristics) that locally modifies favourably conditions for permafrost presence. The terms used in the legend communicate to some degree an uncertainty in the map, and they consequently allow for further interpretations.

A different map signature is used for glaciers, which are by definition not permafrost, although cold glaciers can have permafrost conditions at their bed (e.g. Haeberli, 1976; Luthi and Funk, 2001) and the development of permafrost after the disappearance of temperate glaciers is possible (Kneisel et al., 2000).
The accompanying text describes the most important limitations of the map and explains the usage of the interpretation key. Based on the pictures and the text of the interpretation key, the map user should be able to understand and apply this additional information. A "call for feedback" was sent to several permafrost researchers in Europe. Seven replies helped improve the legend and interpretation key.

\subsection{Evaluation of the permafrost index map}

Comparing the final map index with the distribution of intact and relict rock glaciers shows the model performance in debris-covered areas (Fig. 7). 1863 of the 2403 relict rock glaciers and 42 of the 395 intact rock glaciers show no index value and permafrost is expected to be absent. The majority $(68 \%)$ of the remaining 540 relict rock glaciers lies within a permafrost index $<0.4$, whereas most $(63 \%)$ of the remaining 353 intact rock glaciers are located in areas with an index $>0.5$ (mean index equals 0.58 ). The discrimination of rock glacier status based on predicted permafrost index values results in an AUROC of 0.78 that is an acceptable value according to Hosmer and Lemeshow (2000).

The predicted permafrost index values for borehole temperatures, geophysical investigations and trench or construction sites cover the entire range from 0 to 1 for permafrostexistence observations (Fig. 8) with mean index values of: 0.80 (borehole temperatures), 0.32 (geophysical investigations) and 0.38 (trench or construction sites). The index values of the permafrost-absence observations range from 0 to 0.44 , except for one construction site. The discrimination for these tree observations types shows an AUROC $=0.6$. When neglecting the offset terms discussed in Sect. 4, the 


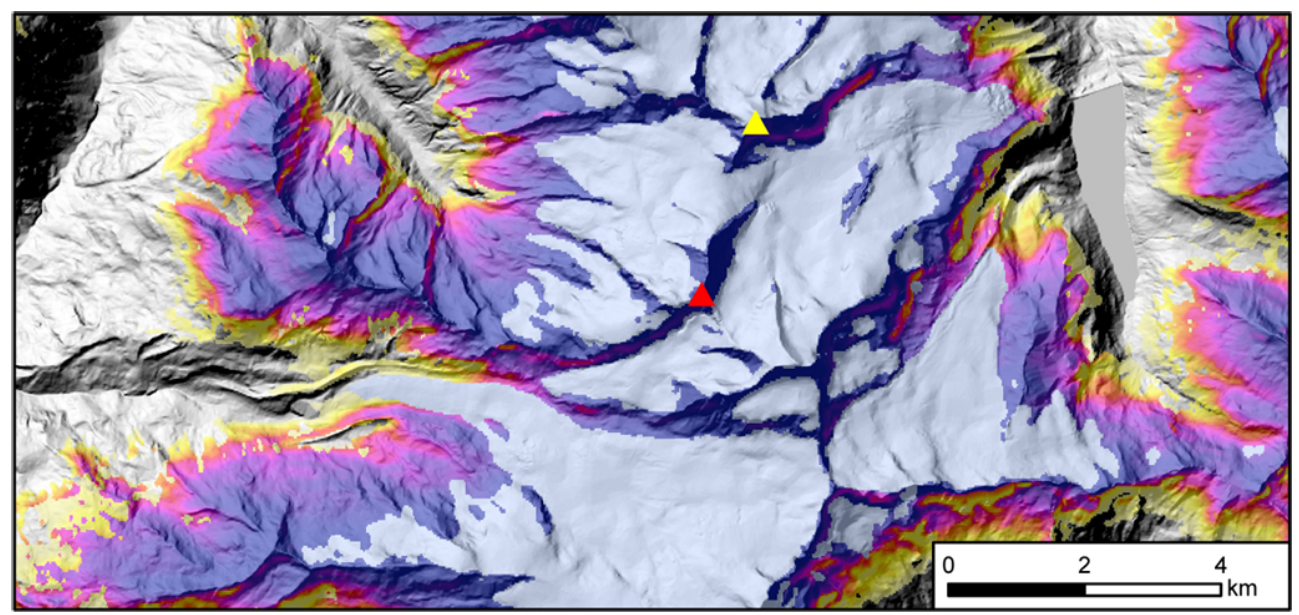

Fig. 5. Alpine Permafrost Index Map (APIM) shown for the area surrounding Rimpfischhorn (4199 m, red triangle) and Allalinhorn (4027 m, yellow triangle) in Switzerland. The map should be interpreted together with the legend and interpretation key (Fig. 10).

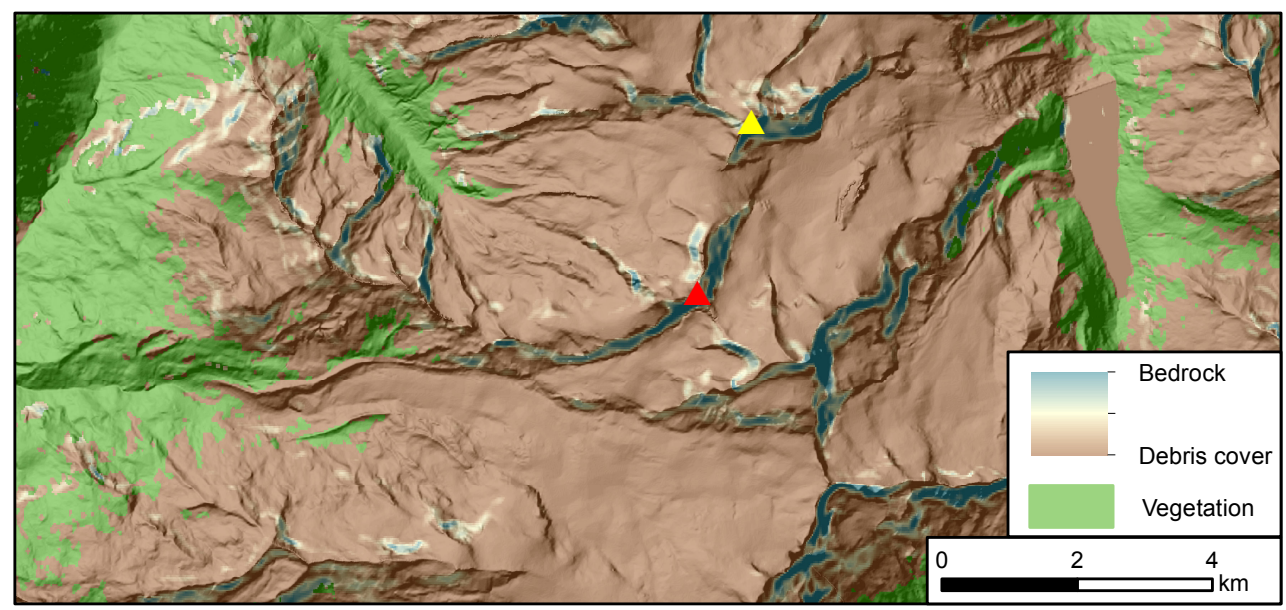

Fig. 6. Surface cover map showing the vegetation mask and the surface class index $m_{r}$ (Eq. 1) for the same area as Fig. 5. To grid cells with a slope angle $\leq 35^{\circ}$ the debris model, for slope angles $\geq 55^{\circ}$ the rock model is used. In between, a fuzzy membership (linear function depending on slope angle) is applied in order to provide a complete spatial coverage of APIM.

AUROC results in 0.56 . If the offset term $\Delta_{\mathrm{Db}}$ is applied based on local terrain and vegetation information provided by Cremonese et al. (2011) instead of vegetation information derived from SAVI, the AUROC results in 0.67.

\subsection{Calculation of summary statistics}

The area potentially influenced by permafrost in the Alps $\left(43^{\circ}-49^{\circ} \mathrm{N}, 4^{\circ}-16^{\circ} \mathrm{E}\right)$ ranges from $2000-12000 \mathrm{~km}^{2}$ (Table 5), and the meaning of this range will be discussed in Sect. 6. The largest extent of permafrost is between 2600 and $3000 \mathrm{~m}$ depending on the index chosen as threshold, whereas the largest area of glaciers is located above $3000 \mathrm{~m}$ (Fig. 9). The offset $\Delta_{\mathrm{Db}}$ that is applied to the debris model for all vegetated pixels plays an important role regarding the final output map or summary statistic. Neglecting $\Delta_{\mathrm{Db}}$ increases
Table 5. Estimated permafrost index areas for the entire Alps. The relative area refers to the total area of the Alps (ca. $200000 \mathrm{~km}^{2}$ ).

\begin{tabular}{lrr}
\hline $\begin{array}{l}\text { Permafrost } \\
\text { index }\end{array}$ & $\begin{array}{r}\text { Total area } \\
\left(\mathrm{km}^{2}\right)\end{array}$ & $\begin{array}{r}\text { Relative area } \\
(\%)\end{array}$ \\
\hline$\geq 0.1$ & 11627 & 6 \\
$\geq 0.5$ & 6220 & 3 \\
$\geq 0.9$ & 2007 & 1 \\
Glaciers & 2056 & 1 \\
\hline
\end{tabular}

the potential permafrost area in the entire Alps by approximately $20 \%$, respectively $3147 \mathrm{~km}^{2}$ (calculated for an index $\geq 0.1$, Table 6). 


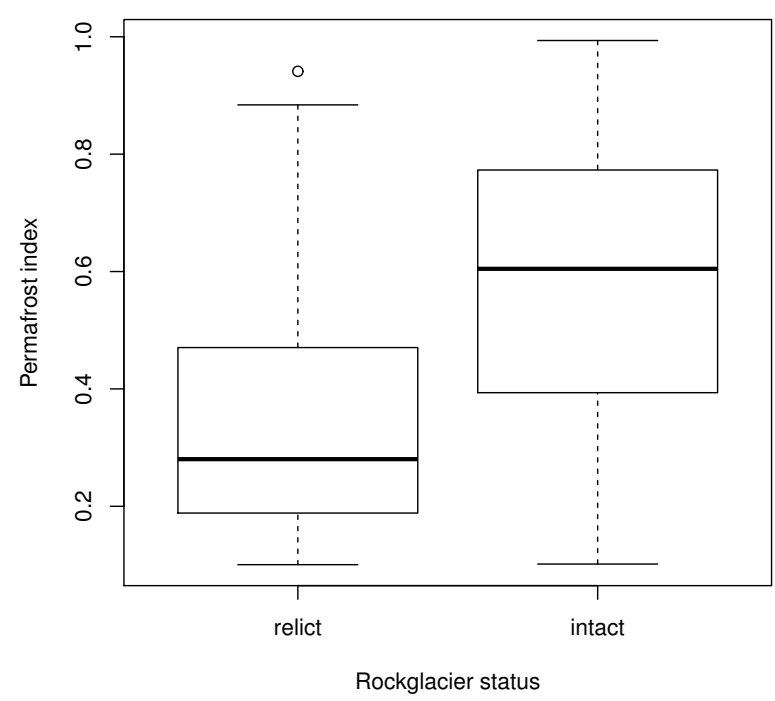

Fig. 7. Permafrost index values for intact and relict rock glaciers that were not used for model calibration. A random point within each rock glacier polygon was used for this figure.

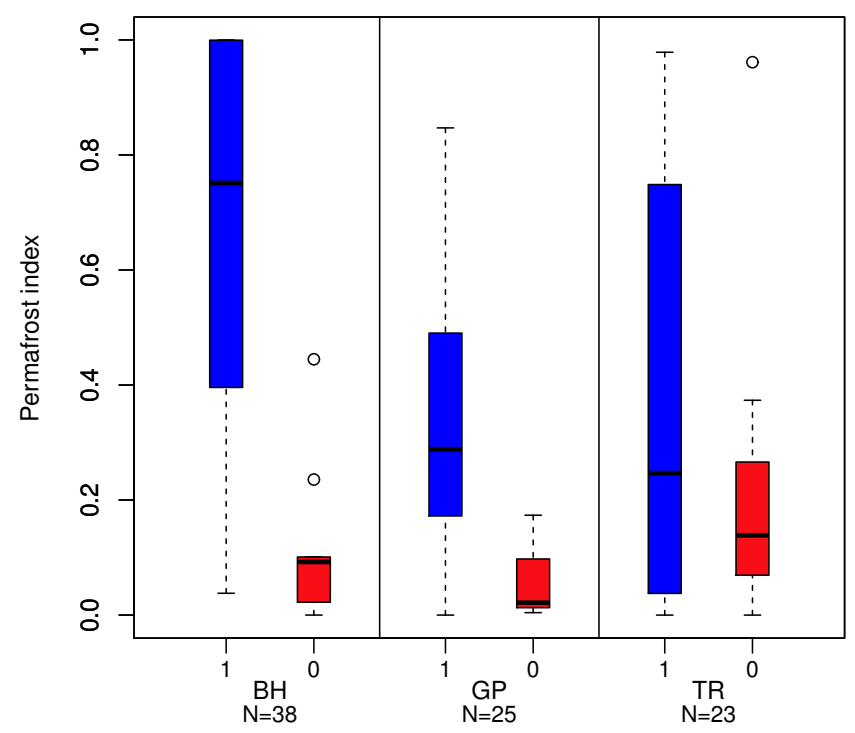

Fig. 8. Box plots showing predicted permafrost index values for the evidence types "Borehole temperatures" (BH), "Geophysical investigations" (GP) and "Trench or construction sites" (TR) for permafrost-existence (1) and permafrost-absence observations (0).

According to this analysis, Switzerland is the country that contains the largest permafrost area (Table 7). In Italy and Austria also large permafrost areas exist.

\section{Discussion}

APIM is based on a larger calibration data set in comparison with other map-based products. Further, existing permafrost
Table 6. Estimated permafrost index areas for the Alps calculated without the offset $\Delta_{\mathrm{Db}}=2{ }^{\circ} \mathrm{C}$ for vegetated areas. $\Delta A$ refers to the difference in area between estimated permafrost distribution calculated with (Table 5) and without offset $\Delta_{\mathrm{Db}}$.

\begin{tabular}{lrr}
\hline $\begin{array}{l}\text { Permafrost } \\
\text { index }\end{array}$ & $\begin{array}{r}\text { Total area } \\
\left(\mathrm{km}^{2}\right)\end{array}$ & $\begin{array}{r}\Delta A \\
\left(\mathrm{~km}^{2}\right)\end{array}$ \\
\hline$\geq 0.1$ & 14774 & 3147 \\
$\geq 0.5$ & 6566 & 346 \\
$\geq 0.9$ & 2011 & 4 \\
\hline
\end{tabular}

distribution models are calibrated for a specific spatial domain or surface type (e.g. using basal temperature of snow (BTS, Haeberli, 1973) measurements in gentle terrain) but later applied to a whole mountain range. This spatial extrapolation that is required for every spatially distributed permafrost model is done in a transparent manner in this work by introducing temperature offsets (Sect. 4).

\subsection{Interpretation of permafrost index area}

The comparison of permafrost index areas obtained in this study with estimates from the literature is complicated by differences in terminology and methods used. Considering index values $\geq 0.5$ is one possible assumption to estimate the area affected by permafrost (see Table 7). For Switzerland, the estimated permafrost area then results in $2163 \mathrm{~km}^{2}$. For comparison, Keller et al. (1998) estimated the permafrost area in Switzerland to range from 4-6\%, which corresponds to approximately $1651-2477 \mathrm{~km}^{2}$. In Austria, $1600 \mathrm{~km}^{2}$ were assigned to mountain permafrost by Ebohon and Schrott (2008) and our estimate is $1557 \mathrm{~km}^{2}$. For France, a value of $1200 \mathrm{~km}^{2}$ is published (PERMAFRANCE, 2010), whereas our estimate is $703 \mathrm{~km}^{2}$.

These estimates are consistent but subject to uncertainties and face the problem of differing or missing definitions for "permafrost area" as described in Sect. 3.3.

\subsection{Evaluation of APMOD}

Existing data (Sect. 3.2) allow to evaluate the map for different surface types, but the following challenges remain: (a) the number of observations is very small compared to the study area, and the observations are strongly biased towards permafrost existence; (b) even less evidence in steep bedrock as well as in intermediate slopes between debris cover and steep bedrock is available; (c) when combing data of different research groups, based on different techniques and coordinate systems, the quality and consistency of the data is a major challenge and errors (e.g. shift in coordinates) cannot be excluded; (d) while the output of APMOD is gridbased with cells having an area of approximately $900 \mathrm{~m}^{2}$, the observations represent point information within a complex, spatially variable mountain topography. This problem relates 
Table 7. Estimated permafrost index areas $\left(\mathrm{km}^{2}\right)$ for the Alpine countries using different index values, and comparison to glacier area $(\mathrm{CH}$ : Switzerland, IT: Italy, AT: Austria, FR: France, DE: Germany, SLO: Slovenia, FL: Liechtenstein).

\begin{tabular}{lrrrr}
\hline Country & Index $\geq 0.1$ & Index $\geq 0.5$ & Index $\geq 0.9$ & Glaciers \\
\hline CH & 3710 & 2163 & 754 & 1010 \\
IT & 3353 & 1786 & 569 & 441 \\
AT & 2907 & 1557 & 484 & 340 \\
FR & 1587 & 703 & 199 & 265 \\
DE & 44.1 & 7.6 & 0.8 & 0.6 \\
SLO & 25.7 & 3.6 & 0.1 & 0.0 \\
FL & 0.3 & 0.0 & 0.0 & 0.0 \\
\hline Total & 11626 & 6220 & 2007 & 2056 \\
\hline
\end{tabular}

to sub-grid variability and scaling issues (cf. Gubler et al., 2011). To address point (c) and (d), $P_{\text {loc }}$ was introduced in Sect. 3.2 to exclude unsuitable evaluation data in this context.

The evaluation of APMOD shows that the prediction of the model is reasonable for rock glaciers and boreholes. For "trench or construction sites" as well as for "geophysical investigations," the predicted permafrost index values are in general too low for permafrost presence, but the discrimination of permafrost absence and presence is correct. All three observation types show low index values for permafrost presence, which means that permafrost is also possible at low index values. Partly, this distribution of index values can be explained by the bias towards permafrost existence observations (mean index value of all observations from Fig. $8=0.35$ ) induced by the tendency of permafrost researchers to choose locations that do have permafrost. The discrimination of the model is slightly worse when the offset terms are not included, which supports our chosen strategy to include them. Further, the model performance increases when introducing local terrain and vegetation information to apply the offset terms. This highlights the importance of small-scale heterogeneity and the potential to improve the model's prediction by using the interpretation key and site observations.

\subsection{Uncertainties and limitations of APMOD}

The temperature offsets used in this study are based on a qualitative assessment of recent literature and on the assumption of spatial and temporal invariance in the model domain. We consider these assumptions and estimates to be the best possible guess given the information available at this time.

The radiation dependent offset $\left(\Delta_{R}\right)$ that is included in the rock model ranges from $-0.5^{\circ} \mathrm{C}$ (minimal PISR) to $-2.84^{\circ} \mathrm{C}$ (maximal PISR), which corresponds to an altitudinal shift of $77-437 \mathrm{~m}$ (assumed surface temperature lapse rate of $0.0065^{\circ} \mathrm{C} \mathrm{m}^{-1}$ ). Minimal and maximal offset terms are based on investigations by Hasler et al. (2011), but the dependencies based on radiation represent a strong

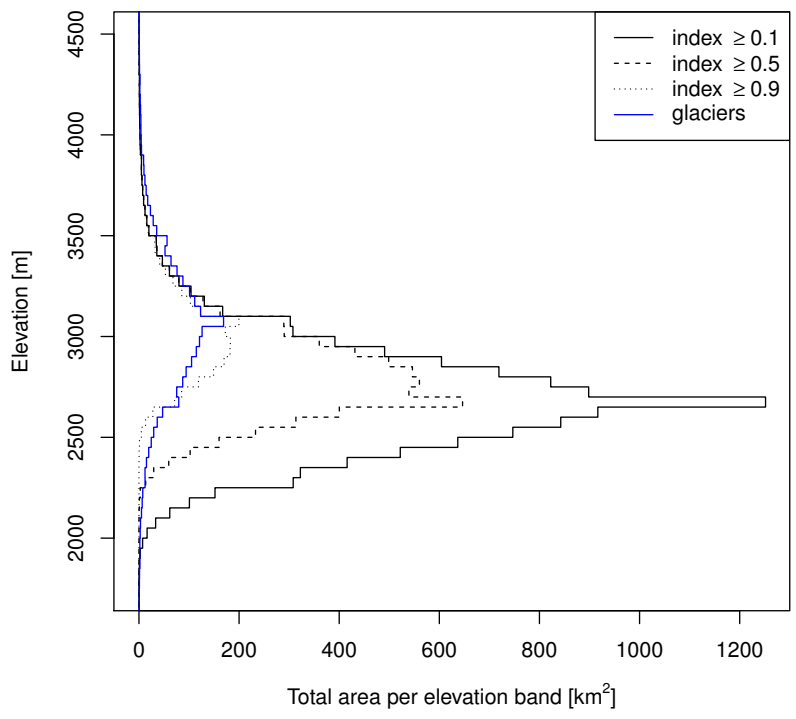

Fig. 9. Altitudinal distribution of permafrost index areas in the Alps, calculated for elevation bands of $50 \mathrm{~m}$.

simplification because no information of the surface and subsurface characteristics is available here. Therefore, the maximal uncertainty of the offset within the rock model is derived from the difference between minimal and maximal offset terms and is estimated to be $2.34^{\circ} \mathrm{C}$ (e.g. an altitudinal shift of the lower permafrost limit of $\pm 360 \mathrm{~m}$ ).

The movement-related offset within the debris model is $+0.5^{\circ} \mathrm{C}$, respectively $70 \mathrm{~m}$, and is based on the mean altitudinal extent of the analysed rock glaciers. The standard error of this mean value is given by the standard deviation of the sample $(81 \mathrm{~m})$ divided by the square root of its quantity $(N=5541)$ and results in $1.1 \mathrm{~m}$. However, local variability of rock glacier extent is not accounted for with this movement-related offset.

The effect of coarse blocks is addressed in the debris model with an offset of $2{ }^{\circ} \mathrm{C}$. Here, we assume that the surface characteristics of rock glaciers are constant and we neglect the fact that rock glaciers with fine-grained material also exist in the Alps (e.g. Matsuoka et al., 2005). As discussed in Sect. 4, published values for this cooling effect range from $1.3{ }^{\circ} \mathrm{C}$ (Juliussen and Humlum, 2008) to $7^{\circ} \mathrm{C}$ (Harris and Pedersen, 1998). Thus, we assume this temperature offset to vary between $-0.7^{\circ} \mathrm{C}$ and $+5^{\circ} \mathrm{C}$, corresponding to an altitudinal variation of the order of -153 to $+770 \mathrm{~m}$.

The discussed uncertainties in the offset terms are large and influence the final permafrost distribution on the map. However, the interpretation key allows the map user to capture some of these extreme topographical situations and to refine the estimate of the map. Isolated permafrost patches in densely vegetated areas and/or below tree line (cf. Gruber and Haeberli, 2009) are not considered in APMOD, but are 
Alpine Permafrost Map: Legend, Interpretation Key and Auxiliary Information

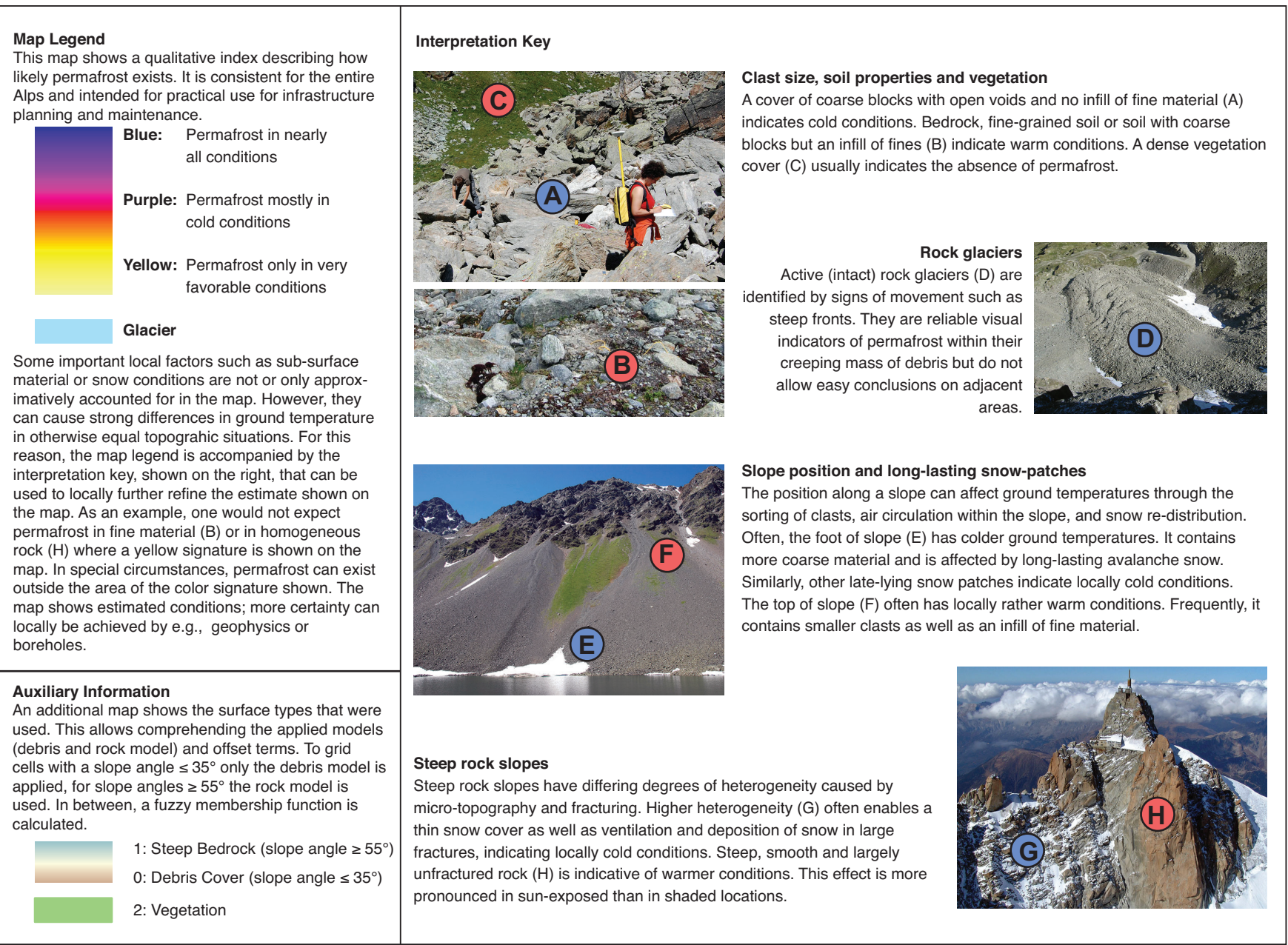

Fig. 10. Legend, interpretation key and auxiliary information that is provided with the Alpine Permafrost Index Map (APIM). This information helps to assess map uncertainties, to relate map contents to their actual expression in terrain and to comprehend the applied models and offset terms.

of minor importance for an Alpine permafrost distribution map.

The classification of the surface types as described in Sect. 3.1 is based on simple approaches, and we distinguish between rock, debris, vegetation and glacier cover. Especially the first two surface types are often hard to differentiate, and all kinds of mixture forms exist in reality. The chosen approach allows classifying these surface types Alpine-wide. For local model application, a more accurate land surface map could be used instead.

APMOD does not account for the recent warming in air temperatures due to climate change and represents a static snapshot of potential permafrost distribution. This is justified because the deviation of an updated and transient permafrost distribution would require knowledge of subsurface ice content that can preserve permafrost conditions for decades. For the purposes of this map ("Where do I need to consider permafrost?"), a steady-state distribution is therefore sufficient and will likely remain relevant in the coming decades.

The rock model was adjusted with longer-term mean annual air temperatures for the period 1961-1990, and predicted MARST values correspond to the same period. Rock wall temperatures react rapidly to climate change (Gruber and Haeberli, 2007), whereas rock glaciers respond with delayed air temperatures due to high ice content (e.g. Haeberli et al., 2006) and coarse blocky surface. Additionally, transient effects, as well as three-dimensional topographical effects, can be responsible for colder temperatures at larger depth than expected based on today's climate conditions (Noetzli and Gruber, 2009). In the final map (APIM), glacier outlines from the year 2003 were used. Because glaciers are subject to fast changes, recently de-glaciated areas need be assessed with caution (cf. Kneisel, 2004; Kneisel and Kääb, 2007). 


\section{Conclusions}

The statistical model of Boeckli et al. (2012) was applied to estimate the current permafrost distribution in the European Alps. This is the first uniform modelling approach that includes all Alpine countries. The Alpine Permafrost Index Map (APIM) uses a grid spacing of approximately $30 \mathrm{~m}$ and an index ranging from 0 to 1 . A high index value points to permafrost in nearly all conditions, and a low index value means permafrost exists only in locally very favourable conditions. Together with the legend and interpretation key, this product should be useful for both researchers and stakeholders to estimate the permafrost distribution for a given region in the European Alps. The main conclusions from this study are the following:

- The transition of a statistical permafrost distribution model to a permafrost map requires a generalization of the model to other surface types than those used for model calibration. Therefore, additional offset terms were defined qualitatively based on the literature; however, they involve some degree of subjectivity. That is why the map is based on index values and not on pure probabilities.

- Evaluation of spatially distributed models predicting permafrost is challenging because test data are limited and its distribution biased towards permafrost presence. For future model calibration and evaluation, ground truth data need to be collected using a suitable sampling design in order to avoid site selection bias inherent in convenience sampling.

- Calculated permafrost index areas provide an indication of possible permafrost extents in different subregions of the Alps. The relative area of permafrost occurrence in relation to the total area of the Alps is estimated to be $3 \%$ when considering an index $\geq 0.5$.

\section{Data availability}

The APIM is freely available for download at: http://doi. pangaea.de/10.1594/PANGAEA.784450 in georeferenced png format. Additionally, the interpretation key (Fig. 10) and the surface-cover map (cf. Fig. 6), which define the used vegetation mask as well as the distinction of debris cover and bedrock based on slope angle, are available. Alternatively, all data are available as a kmz overlay for Google Earth and as a Web Mapping Service for use in a GIS environment (accessible at: http://www.geo.uzh.ch/microsite/ cryodata/PF_map_explanation.html).
Acknowledgements. Funding of this study was partly provided by the Alpine Space Program project PermaNET, the Bavarian Environment Agency (Bayerisches Landesamt für Umwelt, LfU), the Swiss Federal Office for the Environment (Bundesamt für Umwelt, BAFU), the Autonomous Province of Bolzano and the Region of Veneto, Geological Survey. The precipitation data were provided by the ALP-IMP project (http://www.cru.uea.ac.uk/cru/data/alpine/). Landsat scenes are available online (GLOVIS, http://glovis.usgs.gov). Vector25 was provided by the Federal Office of Topography, swisstopo. We thank Wilfried Haeberli for his input on a previous version of this manuscript. Constructive comments on the interpretation key by several colleagues are gratefully acknowledged.

Edited by: D. Riseborough

\section{References}

BAFU: Hinweiskarte der potentiellen Permafrostverbreitung in der Schweiz, Swiss Federal Office for the Environment (FOEN), 2005.

Barsch, D.: Active rock glaciers as indicators for discontinuous alpine permafrost, An example from the Swiss Alps, in: Proceedings of the 3th International Conference on Permafrost, Edmonton, Canada, 10-13 July, 1, 349-352, 1978.

Bodin, X.: Géodynamique du Pergélisol Alpin: Fonctionnement, distribution et évolution récente, L'Exemple du Massif du Combeynot (Hautes Alpe), Ph.D. thesis, Université Denis Diderot Paris 7, France, 2007.

Boeckli, L., Brenning, A., Gruber, S., and Noetzli, J.: A statistical approach to modelling permafrost distribution in the European Alps or similar mountain ranges, The Cryosphere, 6, 125-140, doi:10.5194/tc-6-125-2012, 2012.

Bonnaventure, P. P., Lewkowicz, A. G., Kremer, M., and Sawada, M. C.: A Permafrost Probability Model for the Southern Yukon and Northern British Columbia, Canada, Permafrost Periglac., 23, 52-68, doi:10.1002/ppp.1733, 2012.

Brenning, A.: Statistical geocomputing combining R and SAGA: The example of landslide susceptibility analysis with generalized additive models, SAGA-Seconds Out, 19, 23-32, 2008.

Brenning, A., Gruber, S., and Hoelzle, M.: Sampling and statistical analyses of BTS measurements, Permafrost Periglac., 16, 383393, doi:10.1002/ppp.541, 2005.

Cohen, J.: A Coefficient of Agreement for Nominal Scales, Educ. Psychol. Meas., 20, 37-46, doi:10.1177/001316446002000104, 1960.

Cremonese, E., Gruber, S., Phillips, M., Pogliotti, P., Boeckli, L., Noetzli, J., Suter, C., Bodin, X., Crepaz, A., Kellerer-Pirklbauer, A., Lang, K., Letey, S., Mair, V., Morra di Cella, U., Ravanel, L., Scapozza, C., Seppi, R., and Zischg, A.: Brief Communication: "An inventory of permafrost evidence for the European Alps", The Cryosphere, 5, 651-657, doi:10.5194/tc-5-651-2011, 2011.

Delaloye, R., Reynard, E., Lambiel, C., Marescot, L., and Monnet, R.: Thermal anomaly in a cold scree slope (Creux du Van, Switzerland), in: Proceedings of the 8th International Conference on Permafrost, Zurich, Switzerland, 1, 175-180, 2003.

Ebohon, B. and Schrott, L.: Modeling mountain permafrost distribution: A new map of Austria, in: Proceedings of the 9th Interna- 
tional Conference on Permafrost, Fairbanks, Alaska, 30 June-3 July, 397-402, 2008.

Etzelmüller, B., Farbrot, H., Gudhmundsson, A., Humlum, O., Tveito, O., and Björnsson, H.: The regional distribution of mountain permafrost in Iceland, Permafrost Periglac., 18, 185-199, doi:10.1002/ppp.583, 2007.

Fontana, F., Rixen, C., Jonas, T., Aberegg, G., and Wunderle, S.: Alpine Grassland Phenology as Seen in AVHRR, VEGETATION, and MODIS NDVI Time Series - a Comparison with In Situ Measurements, Sensors, 8, 2833-2853, doi:10.3390/s8042833, 2008.

Frauenfelder, R.: Rock glaciers, Fletschhorn Area, Valais, Switzerland, International Permafrost Association, Data and Information Working Group, NSIDC, University of Colorado at Boulder, 1998.

Frauenfelder, R., Schneider, B., and Kääb, A.: Using dynamic modelling to simulate the distribution of rockglaciers, Geomorphology, 93, 130-143, doi:10.1016/j.geomorph.2006.12.023, 2008.

Gorbunov, A. P., Marchenko, S. S., and Seversky, E. V.: The thermal environment of blocky materials in the mountains of Central Asia, Permafrost Periglac., 15, 95-98, doi:10.1002/ppp.478, 2004.

Gruber, S.: Derivation and analysis of a high-resolution estimate of global permafrost zonation, The Cryosphere, 6, 221-233, doi:10.5194/tc-6-221-2012, 2012.

Gruber, S. and Haeberli, W.: Permafrost in steep bedrock slopes and its temperature-related destabilization following climate change, J. Geophys. Res., 112, F02S18, doi:10.1029/2006JF000547, 2007.

Gruber, S. and Haeberli, W.: Mountain permafrost, in: Permafrost Soils, edited by: Margesin, R., Biology Series, Springer, 16, 3344, doi:10.1007/978-3-540-69371-0_3, 2009.

Gruber, S. and Hoelzle, M.: Statistical modelling of mountain permafrost distribution: local calibration and incorporation of remotely sensed data, Permafrost Periglac., 12, 69-77, doi:10.1002/ppp.374, 2001

Gruber, S. and Hoelzle, M.: The cooling effect of coarse blocks revisited: a modeling study of a purely conductive mechanism, in: Proceedings of the 9th International Conference on Permafrost, Fairbanks, Alaska, 30 June-3 July, 1, 557-561, 2008.

Gruber, S., Peter, M., Hoelzle, M., Woodhatch, I., and Haeberli, W.: Surface temperatures in steep Alpine rock faces - a strategy for regional-scale measurement and modelling, in: Proceedings of the 8th International Conference on Permafrost, Zurich, Switzerland, 21-25 July, 1, 325-330, 2003.

Gubler, S., Fiddes, J., Keller, M., and Gruber, S.: Scaledependent measurement and analysis of ground surface temperature variability in alpine terrain, The Cryosphere, 5, 431-443, doi:10.5194/tc-5-431-2011, 2011.

Haeberli, W.: Die Basis-Temperatur der winterlichen Schneedecke als möglicher Indikator für die Verbreitung von Permafrost in den Alpen, Zeitschrift für Gletscherkunde und Glazialgeologie, IX/1/2, 221-227, 1973.

Haeberli, W.: Untersuchungen zur Verbreitung von Permafrost zwischen Flüelapass und Piz Grialetsch (Graubünden), Mitteilungen der Versuchsanstalt für Wasserbau, Hydrologie und Glaziologie der ETH Zürich, Zurich, Switzerland, 17, 221 pp., 1975.
Haeberli, W.: Eistemperaturen in den Alpen, Zeitschrift für Gletscherkunde und Glazialgeologie, 11, 203-220, 1976.

Haeberli, W., Hallet, B., Arenson, L., Elconin, R., Humlum, O., Kääb, A., Kaufmann, V., Ladanyi, B., Matsuoka, N., Springman, S., and Mühll, D. V.: Permafrost creep and rock glacier dynamics, Permafrost Periglac., 17, 189-214, doi:10.1002/ppp.561, 2006.

Hanson, S. and Hoelzle, M.: Installation of a shallow borehole network and monitoring of the ground thermal regime of a high alpine discontinuous permafrost environment, Eastern Swiss Alps, Norsk Geogr. Tidsskr., 59, 84-93, doi:10.1080/00291950510020664, 2005.

Harris, C., Arenson, L. U., Christiansen, H. H., Etzelmüller, B., Frauenfelder, R., Gruber, S., Haeberli, W., Hauck, C., Hölzle, M., Humlum, O., Isaksen, K., Kääb, A., Kern-Lütschg, M. A., Lehning, M., Matsuoka, N., Murton, J. B., Nötzli, J., Phillips, M., Ross, N., Seppälä, M., Springman, S. M., and Mühll, D. V.: Permafrost and climate in Europe: Monitoring and modelling thermal, geomorphological and geotechnical responses, Earth-Sci Rev., 92, 117-171, doi:10.1016/j.earscirev.2008.12.002, 2009.

Harris, S. and Pedersen, D.: Thermal regimes beneath coarse blocky materials, Permafrost Periglac., 9, 107-120, doi:10.1002/(SICI)1099-1530(199804/06)9:2<107::AIDPPP277>3.0.CO;2-G, 1998.

Hasler, A., Gruber, S., and Haeberli, W.: Temperature variability and offset in steep alpine rock and ice faces, The Cryosphere, 5, 977-988, doi:10.5194/tc-5-977-2011, 2011.

Hayakawa, Y., Oguchi, T., and Lin, Z.: Comparison of new and existing global digital elevation models: ASTER GDEM and SRTM-3, Geophys. Res. Lett., 35, L17404, doi:10.1029/2008GL035036, 2008.

Heggem, E., Juliussen, H., and Etzelmüller, B.: Mountain permafrost in central-eastern Norway, Norsk Geogr. Tidsskr., 59, 94-108, doi:10.1080/00291950510038377, 2005.

Hijmans, R. J. and van Etten, J.: raster: Geographic analysis and modeling with raster data, $\mathrm{R}$ package version $1.9-64$, The $\mathrm{R}$ Foundation for Statistical Computing, Vienna, 2012.

Hoelzle, M.: Permafrost occurrence from BTS measurements and climatic parameters in the Eastern Swiss Alps, Permafrost Periglac., 3, 143-147, doi:10.1002/ppp.3430030212, 1992.

Hoelzle, M.: Permafrost und Gletscher im Oberengadin: Grundlagen und Anwendungsbeispiele für automatisierte Schätzverfahren, Mitteilungen der VAW-ETH Zurich, 132, 121 pp., 1994.

Hoelzle, M., Haeberli, W., and Keller, F.: Application of BTSmeasurements for modelling permafrost distribution in the Swiss Alps, in: Proceedings of the 6th International Conference on Permafrost, South China University Technology Press, Beijing, 272-277, 1993.

Hoelzle, M., Haeberli, W., and Stocker-Mittaz, C.: Miniature ground temperature data logger measurements 2000-2002 in the Murtèl-Corvatsch area, Eastern Swiss Alps, in: Proceedings of the 8th International Conference on Permafrost. Zurich, Switzerland, 21-25 July, 419-424, 2003.

Hosmer, D. and Lemeshow, S.: Applied logistic regression, WileyInterscience, New York, 2000.

Huete, A.: A soil-adjusted vegetation index (SAVI), Remote Sens. Environ., 25, 295-309, doi:10.1016/0034-4257(88)90106X, 1988 . 
Humlum, O.: Active layer thermal regime at three rock glaciers in Greenland, Permafrost Periglac., 8, 383-408, doi:10.1002/(SICI)1099-1530(199710/12)8:4<383::AIDPPP265>3.0.CO;2-V, 1997.

Imhof, M.: Modelling and verification of the permafrost distribution in the Bernese Alps, Switzerland, Permafrost Periglac., 17, 267280, doi:10.1002/(SICI)1099-1530(199609)7:3<267::AIDPPP221>3.0.CO;2-L, 1996.

International Organization for Standardization: International Standard Atmosphere, Standard Atmosphere ISO 2533:1975, 1975.

Janke, J. R.: The occurrence of alpine permafrost in the Front Range of Colorado, Geomorphology, 67, 375-389, doi:10.1016/j.geomorph.2004.11.005, 2004.

Juliussen, H. and Humlum, O.: Thermal regime of openwork block fields on the mountains Elgåhogna and Sølen, central-eastern Norway, Permafrost Periglac., 19, 1-18, doi:10.1002/ppp.607, 2008.

Keller, F.: Automated mapping of mountain permafrost using the program PERMAKART within the geographical information system ARC/INFO, Permafrost Periglac., 3, 133-138, doi:10.1002/ppp.3430030210, 1992.

Keller, F., Frauenfelder, R., Hoelzle, M., Kneisel, C., Lugon, R., Phillips, M., Reynard, E., and Wenker, L.: Permafrost map of Switzerland, in: Proceedings of the 7th International Conference on Permafrost, Nordicana, Yellowknife, Canada, 23-27 June, 557-562, 1998.

Kneisel, C.: New insights into mountain permafrost occurrence and characteristics in glacier forefields at high altitude through the application of 2D resistivity imaging, Permafrost Periglac., 15, 221-227, doi:10.1002/ppp.495, 2004.

Kneisel, C. and Kääb, A.: Mountain permafrost dynamics within a recently exposed glacier forefield inferred by a combined geomorphological, geophysical and photogrammetrical approach, Earth Surf. Proc. Landforms, 32, 1797-1810, doi:10.1002/esp.1488, 2007.

Kneisel, C., Haeberli, W., and Baumhauer, R.: Comparison of spatial modelling and field evidence of glacier/permafrost relations in an Alpine permafrost environment, Ann. Glaciol., 31, 269274, 2000.

Lambiel, C. and Reynard, E.: Regional modelling of present, past and future potential distribution of discontinuous permafrost based on a rock glacier inventory in the Bagnes-Heé reé mence area (Western Swiss Alps), Norsk Geogr. Tidsskr., 55, 219-223, 2001.

Lewkowicz, A. and Bonnaventure, P.: Interchangeability of mountain permafrost probability models, northwest Canada, Permafrost Periglac., 19, 49-62, doi:10.1002/ppp.612, 2008.

Lewkowicz, A. G. and Ednie, M.: Probability mapping of mountain permafrost using the BTS method, Wolf Creek, Yukon Territory, Canada, Permafrost Periglac., 15, 67-80, doi:10.1002/ppp.480, 2004.
Li, J., Sheng, Y., Wu, J., Chen, J., and Zhang, X.: Probability distribution of permafrost along a transportation corridor in the northeastern Qinghai province of China, Cold Regions Sci. Technol., 59, 12-18, doi:10.1016/j.coldregions.2009.05.012, 2009.

Luthi, M. P. and Funk, M.: Modelling heat flow in a cold, high-altitude glacier: interpretation of measurements from Colle Gnifetti, Swiss Alps, J. Glaciol., 47, 314-324, doi:10.3189/172756501781832223, 2001.

Mason, S. and Graham, N.: Areas beneath the relative operating characteristics (roc) and relative operating levels (rol) curves: Statistical significance and interpretation, Q. J. Royal Meteorol. Soc., 128, 2145-2166, doi:10.1256/003590002320603584, 2002.

Matsuoka, N., Ikeda, A., and Date, T.: Morphometric analysis of solifluction lobes and rock glaciers in the Swiss Alps, Permafrost Periglac., 16, 99-113, doi:10.1002/ppp.517, 2005.

Noetzli, J. and Gruber, S.: Transient thermal effects in Alpine permafrost, The Cryosphere, 3, 85-99, doi:10.5194/tc-3-85-2009, 2009.

Olaya, V.: A gentle introduction to SAGA GIS, edition 1.1, user's guide, University of Göttingen, Göttingen, Germany, available at: http://www.saga-gis.org/en/index.html(last access: 25 July 2012), 2004.

Paul, F., Frey, H., and Le Bris, R.: A new glacier inventory for the European Alps from Landsat TM scenes of 2003: Challenges and results, Ann. Glaciol., 52, 144-152, 2011.

PERMAFRANCE: Permafrost in France, edited by: Schoeneich, P., Bodin, X., Krysiecki, J. M., Deline, P., and Ravanels, L., Permafrance Network, Report Nr. 1, 68 pp., 2010.

Pogliotti, P.: Influence of snow cover on MAGST over complex morphologies in mountain permafrost regions, $\mathrm{Ph} . \mathrm{D}$. thesis, Earth Science Department, University of Turin, Italy, 2010.

R Development Core Team: Development Core Team: R: a language and environment for statistical computing, $\mathrm{R}$ Foundation for Statistical Computing, Vienna, Austria, ISBN 3-900051-07-0, available at: http://www.R-project.org, 2010.

Serrano, E., Agudo, C., Delaloye, R., and Gonzalez-Trueba, J.: Permafrost distribution in the Posets massif, Central Pyrenees, Norsk Geogr. Tidsskr., 55, 245-252, 2001.

swisstopo: Vector25 - das digitale Landschaftsmodell der Schweiz, Bundesamt für Landestopographie, Wabern (CH), 2007.

Tanarro, L., Hoelzle, M., García, A., Ramos, M., Gruber, S., Gómez, A., Piquer, M., and Palacios, D.: Permafrost distribution modelling in the mountains of the Mediterranean: Corral del Veleta, Sierra Nevada, Spain, Norsk Geogr. Tidsskr., 55, 253260, 2001.

Zhang, T., Heginbottom, J. A., Barry, R. G., and Brown, J.: Further statistics on the distribution of permafrost and ground ice in the Northern Hemisphere, Polar Geography, 24, 126-131, doi:10.1080/10889370009377692, 2000. 